\title{
NPUST's practice on achieving sustainable development goals
}

\author{
C.-H. Tai ${ }^{1}$, C.-L. Chang ${ }^{2}$, and J.C. Leong ${ }^{3 *}$ \\ ${ }^{1}$ President, National Pingtung University of Science and Technology, Taiwan \\ ${ }^{2}$ Dean, Office of General Affairs, National Pingtung University of Science and Technology, Taiwan \\ ${ }^{3}$ Dean, International College, National Pingtung University of Science and Technology, Taiwan
}

\begin{abstract}
The National Pingtung University of Science and Technology was established as an agricultural institution in 1924. Since then, this educational institution has been one of the key role players in developing the agricultural advancement in Taiwan. For years, the university has seriously planned and carried out projects that strengthen her identity, "being green". Under the scope of university's uniqueness and responsibility, measures taken in the university directly involves administrative affairs, such as teaching, research, university development, student welfare, etc. As a matter of fact, initiating new policies, measures, and projects is only the beginning of everything. Without proper planning, enforcement, and funding, any one of these policies, measures, and projects may end up going nowhere. In other words, sustainability is absolutely the most critical element that dictates the success of the policies, measures, and projects. This sustainability covers financial allocation, manpower, negotiation, evaluation, and adjustments. The university has invested a lot of funding and effort to achieve the aforementioned goals through various means in the aspects of administration, education, research and development.
\end{abstract}

\section{Introduction}

The United Nations [1] has compiled 17 Sustainable Development Goals (SDGs) for global welfare which widely cover a range of topics associated to social and economic developments for all countries regardless if the country is a "developed" or "developing" nation. These goals address issues related to poverty, hunger, health, education, climate change, gender equality, water, sanitation, energy, environment and social justice, whose relative importance and exact wording are listed in Table 1. Apparently, poverty, hunger, and health are the three most important ones and they are somewhat very closely connected to each other. Poverty leads to hunger and then undernourishment. This later causes serious health problem. To break this circle of difficulty, one needs to identify its root. As a matter of fact, agriculture itself has provided the largest portion of world employment and has contributed to the largest source of income for poor rural households. It has supported the livelihoods for $40 \%$ of the world population. In some parts of Asia and Africa, more than $40 \%$ of the agricultural labor force actually come from women. Because of poor agricultural technology and efficiency, crop yield is obviously low, risk for production has become higher lately due to climate change, etc. These lead to poverty, hunger, and poor nutrition. Currently, one out of every two deaths in children under five is owing to poor nutrition. Majority of these cases happen in developing countries. The International Food Policy Research Institute (IFPRI) [2] believes that eliminating hunger and under-nutrition should have higher priority to ending poverty. They suggested that the solutions should be: 1) agriculture-led; 2) social protection- and nutrition intervention-led; or 3 ) a combination of both of these approaches.

The National Pingtung University of Science and Technology was established in 1924 as an agricultural institution. For almost a century, this educational institution has great contributions in the advancement of Taiwan's agricultural sectors through funded projects from various governmental agencies and private sectors. To be "green", the university undertakes measures involving teaching, research, university development, student welfare, and so on to initiate new policies, to brainstorm the measures, and to carry out the projects. Without proper planning, enforcement, and funding, each of these policies, measures, and projects may eventually go in vain. In the entire process, sustainability is clearly one of the most important questions needs to be raised continuously to ensure the sustainability especially in financial status and workforce. On-going evaluation is then needed for future adjustments.

Table 1. List of UN Sustainable Development Goals (SDGs) [1]

\begin{tabular}{|l|l|l|}
\hline No. & Goal & $\begin{array}{l}\text { Exact wording of } \\
\text { the goal }\end{array}$ \\
\hline 1 & No Poverty & $\begin{array}{l}\text { "End poverty in all its } \\
\text { forms everywhere." }\end{array}$ \\
\hline 2 & Zero Hunger & $\begin{array}{l}\text { "End hunger, achieve } \\
\text { food security and } \\
\text { improved nutrition } \\
\text { and promote } \\
\text { sustainable }\end{array}$ \\
\hline
\end{tabular}




\begin{tabular}{|c|c|c|}
\hline & & agriculture" \\
\hline 3 & $\begin{array}{l}\text { Good Health and } \\
\text { Well-Being for } \\
\text { people }\end{array}$ & $\begin{array}{l}\text { "Ensure healthy lives } \\
\text { and promote well- } \\
\text { being for all at all } \\
\text { ages." }\end{array}$ \\
\hline 4 & Quality Education & $\begin{array}{l}\text { "Ensure inclusive and } \\
\text { equitable quality } \\
\text { education and } \\
\text { promote lifelong } \\
\text { learning opportunities } \\
\text { for all." }\end{array}$ \\
\hline 5 & Gender Equality & $\begin{array}{l}\text { "Achieve gender } \\
\text { equality and } \\
\text { empower all women } \\
\text { and girls." }\end{array}$ \\
\hline 6 & $\begin{array}{l}\text { Clean Water and } \\
\text { Sanitation }\end{array}$ & $\begin{array}{l}\text { "Ensure availability } \\
\text { and sustainable } \\
\text { management of water } \\
\text { and sanitation for } \\
\text { all." }\end{array}$ \\
\hline 7 & $\begin{array}{l}\text { Affordable and } \\
\text { Clean Energy }\end{array}$ & $\begin{array}{l}\text { "Ensure access to } \\
\text { affordable, reliable, } \\
\text { sustainable and } \\
\text { modern energy for } \\
\text { all." }\end{array}$ \\
\hline 8 & $\begin{array}{l}\text { Decent Work and } \\
\text { Economic Growth }\end{array}$ & $\begin{array}{l}\text { "Promote sustained, } \\
\text { inclusive and } \\
\text { sustainable economic } \\
\text { growth, full and } \\
\text { productive } \\
\text { employment and } \\
\text { decent work for all." }\end{array}$ \\
\hline 9 & $\begin{array}{l}\text { Industry, } \\
\text { Innovation } \\
\text { and Infrastructure }\end{array}$ & $\begin{array}{l}\text { "Build resilient } \\
\text { infrastructure, } \\
\text { promote inclusive } \\
\text { and sustainable } \\
\text { industrialization and } \\
\text { foster innovation." }\end{array}$ \\
\hline 10 & $\begin{array}{l}\text { Reduced } \\
\text { Inequalities }\end{array}$ & $\begin{array}{l}\text { "Reduce income } \\
\text { inequality within and } \\
\text { among countries." }\end{array}$ \\
\hline 11 & $\begin{array}{l}\text { Sustainable Cities } \\
\text { and Communities }\end{array}$ & $\begin{array}{l}\text { "Make cities and } \\
\text { human settlements } \\
\text { inclusive, safe, } \\
\text { resilient and } \\
\text { sustainable." }\end{array}$ \\
\hline 12 & $\begin{array}{l}\text { Responsible } \\
\text { Consumption and } \\
\text { Production }\end{array}$ & $\begin{array}{l}\text { "Ensure sustainable } \\
\text { consumption and } \\
\text { production patterns." }\end{array}$ \\
\hline 13 & Climate Change & $\begin{array}{l}\text { "Take urgent action } \\
\text { to combat climate } \\
\text { change and its } \\
\text { impacts by regulating } \\
\text { emissions and } \\
\text { promoting } \\
\text { developments in } \\
\text { renewable energy." }\end{array}$ \\
\hline 14 & Life Below Water & $\begin{array}{l}\text { "Conserve and } \\
\text { sustainably use the } \\
\text { oceans, seas and } \\
\text { marine resources for }\end{array}$ \\
\hline
\end{tabular}

\begin{tabular}{|c|c|c|}
\hline & & $\begin{array}{l}\text { sustainable } \\
\text { development." }\end{array}$ \\
\hline 15 & Life on Land & $\begin{array}{l}\text { "Protect, restore and } \\
\text { promote sustainable } \\
\text { use of terrestrial } \\
\text { ecosystems, } \\
\text { sustainably manage } \\
\text { forests, combat } \\
\text { desertification, and } \\
\text { halt and reverse land } \\
\text { degradation and halt } \\
\text { biodiversity loss." }\end{array}$ \\
\hline 16 & $\begin{array}{l}\text { Peace, Justice and } \\
\text { Strong } \\
\text { Institutions }\end{array}$ & $\begin{array}{l}\text { "Promote peaceful } \\
\text { and inclusive } \\
\text { societies for } \\
\text { sustainable } \\
\text { development, provide } \\
\text { access to justice for } \\
\text { all and build } \\
\text { effective, accountable } \\
\text { and inclusive } \\
\text { institutions at all } \\
\text { levels." }\end{array}$ \\
\hline 17 & $\begin{array}{l}\text { Partnerships for } \\
\text { the Goals }\end{array}$ & $\begin{array}{l}\text { "Strengthen the } \\
\text { means of } \\
\text { implementation and } \\
\text { revitalize the global } \\
\text { partnership for } \\
\text { sustainable } \\
\text { development." }\end{array}$ \\
\hline
\end{tabular}

\section{Approaches}

\subsection{Administration}

There are many measures undertaken in the university to achieve sustainable development within the campus. Three of the most successful examples are the implementation of heat pump system in student dormitories, the handling of waste, and the use of electric motorcycles among new intakes. The use of heat pump system in the student dormitories has been a long journey because the university has to go through many processes to get the project going. As a national university, the university budget is not only tight but also under supervision of the government. As a result, the administrators in the university have to come to a consensus recognizing the impact the heat pump system may have on the university's path to being green. Then, the budget required for this system has to be planned, proposed, and approved. Those who mainly involve include the Office of General Affairs, the Office of Student Affairs, and the Accounting Office. The waste handling is critical for any university to protect our environment and to maintain its sustainability. As an agricultural university, NPUST has developed her own strategy to handle different kinds of waste, such as domestic waste, agricultural waste, chemical waste, etc. The promotion of waste handling involves the Office of General Affairs, the Office of Student Affairs, several student bodies, etc. NPUST freshmen used to rely on 
motorcycles to travel both inside and outside the campus. In recent years, the university has set a goal to reduce the use of gasoline motorcycles by providing subsidy to on-campus/off-campus bus system as well as offering leasing programs for electrical motorcycles to our students. The Dean for the Office of Student Affairs has to ask for financial support from the Department of Transportation, to negotiate leasing programs with electrical motorcycle companies, and to promote the programs among the students and their parents.

\subsection{Educational and activity}

As an educational institution, one of the main goals of NPUST is to educate and to strengthen the understanding of various issues related to environment or sustainability. To raise the awareness, the subjects of target consist of the students enrolled in the university as well as the general public. For the former target, the university puts effort in encouraging the faculty members to relate their course materials to issues about environment or sustainability if the nature of the course permits. The statistical information of these courses is presented in Table 2 .

Table 2. Statistics of courses related to environment and sustainability

\begin{tabular}{|c|c|c|}
\hline Year & Number & Percentage $^{\dagger}$ \\
\hline 2013 & 1731 & $34.46 \%$ \\
\hline 2014 & 1988 & $39.78 \%$ \\
\hline 2015 & 2727 & $50.68 \%$ \\
\hline 2016 & 2731 & $50.82 \%$ \\
\hline
\end{tabular}

number of courses related to environment or sustainability divided by the number of all courses.

In additional to the curriculum, NPUST also promotes the awareness for the importance of environmental and ecology protection through a special unit in the university. The university has established the Center for Environment Protection, Safety and Health (CEPSH) whose main responsibility is to treat and recycle the wastewater generated in the 8 student dormitories and 2 student restaurants. After an upgrade in 2008, this center is capable of treating up to $800 \mathrm{~m}^{3}$ wastewater on a daily basis. Through CEPSH, NPUST organizes activities to educate both NPUST students and the public communities how natural environments function, and particularly, how human beings can manage behavior and ecosystems to attain sustainable mankind. This helps us transitioning to a society that is knowledgeable of the environment and its associated problems, aware of the solutions to these problems, and motivated enough to solve them. It is no doubt a complicated field integrating multiple disciplines ranging from science to engineering and management to humanity. Only through simple yet interesting activities, as listed in Table 3, can CEPSH help inject momentum into the public awareness on ecological, environmental, and social sustainability. Figures 1 are the pictures of the activity.
Table 3. CEPSH educational activities in 2015

\begin{tabular}{|c|c|c|}
\hline Activities & Number & $\begin{array}{c}\text { Total } \\
\text { Number of } \\
\text { Attendees }\end{array}$ \\
\hline Tours/Visits & 53 & 1,538 \\
\hline Workshops/Seminars & 21 & 990 \\
\hline
\end{tabular}

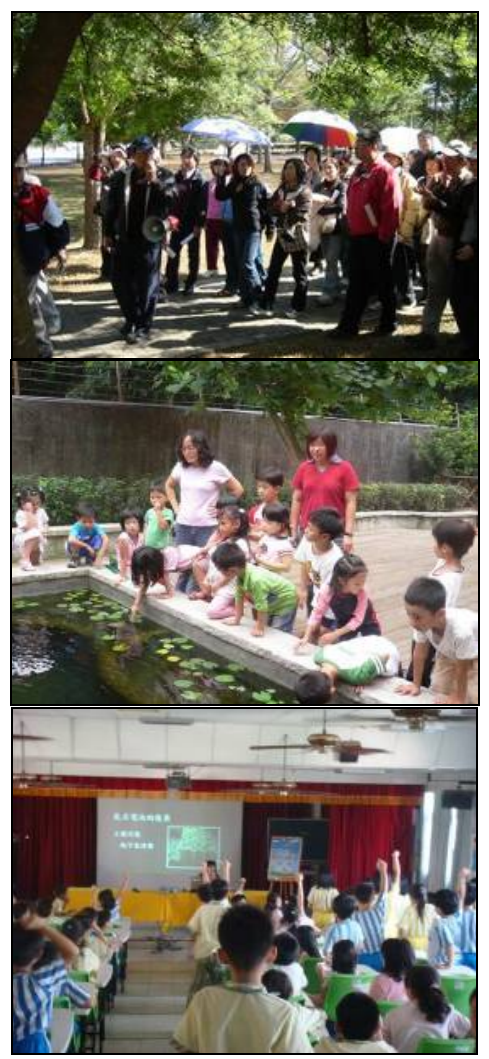

Fig. 1. CEPSH engagement in public education: community visit (top), kindergartners visit (middle), off-campus education (bottom)

\subsection{Research and development}

The third approach NPUST undertakes is related to research and development. Unlike the previous two approaches, this approach may seem to have very little effect on the university itself. However, when successful, it may have a great contribution over the world when the technology developed is widely used in the relevant industry. The followings are some examples:

- Circular economy in forest areas

- Electric car for sloping area maneuver

- High-yield rice cultivation

- Hydroponics

- Power generation using manure

- Recycle of aquaculture water

- Water-saving irrigation technology

\section{Summary/ concluding remarks}

It is important that the university should have a vision to help solve the problems currently faced in the world. Also, the university should have the right attitude to lead 
the society in solving the problems. Since UN has identified the sustainable development goals, NPUST recognizes the importance of these goals and their impacts on our future generation. NPUST vows to keep on the pace to initiate more projects that supports sustainable development goals. Although those identified by $\mathrm{UN}$ are too much for a university to tackle, the university can help preparing the essential elements.

\section{References}

1. Sustainable Development Knowledge Platform. United Nations Department of Public Information. Available online

at https://sustainabledevelopment.un.org/sdgs, accessed on 23 Februari, (2018)

2. Fan, Shenggen. Ending world hunger and undernutrition by 2025. IFPRI BLOG. Available online at http://www.ifpri.org/blog/ending-worldhunger-and-undernutrition-2025, accessed on 25 Feb., 2018. (2014) 